Check for updates

The BMJ

fgodlee@bmj.com Follow Fiona on Twitter @fgodlee

Cite this as: $B M / 2020 ; 369: m 2518$ http://dx.doi.org/10.1136/bmj.m2518 Published: 26 June 2020

\section{Covid 19: Where's the strategy for testing?}

\section{Fiona Godlee editor in chief}

It would be nice to be able to say otherwise, but the UK's approach to testing in this covid-19 pandemic continues to be chaotic, centralised, commercialised, and driven by numerical targets rather than clear strategy. Allan Wilson, president of the Institute of Biomedical Sciences, has called this reactive and random approach the "wild west of testing." "Writing for BMJ Opinion this week, Chris Ham agrees. The system is far from "world beating," and ministers must be prepared to acknowledge and learn from mistakes, he says. ${ }^{2}$

What makes matters worse is the ongoing lack of honesty. The government has exaggerated the performance of its much vaunted test, track, and trace system: most contacts were traced by local health teams, with only a minority by the national, privately contracted call centres. ${ }^{3}$ Some reasons for this are grimly outlined by one doctor who signed up to work in them. ${ }^{4}$

As for antibody testing, 5 there are the same mistakes. Heralded by our political leaders as "game changing" and an "important milestone," antibody testing is being ramped up, with healthcare trusts being asked to be ready to rapidly process thousands of tests a day. But a group of public health and clinical experts warn that this makes no sense ${ }^{6}$ : these tests are not useful in diagnosis and can't be relied on to decide whether someone has been infected or is now immune. The only current justification for such large scale testing is for research and public health surveillance, they say.

Also lacking is reliable information on test accuracy, says Jon Deeks, lead author of an imminent Cochrane review of covid-19 antibody tests and The BMJ's chief statistician. The reported sensitivities and specificities are based on poor science or manufacturers' marketing material, he says in our report. ${ }^{7}$ Nor have the tests been validated in real world situations. As for the costs, we know that £16m went on tests from China that proved inadequate, but we don't know how much has been spent on contracts with Roche or Abbott, as these details have not been disclosed.

Tests are just one of many commercial opportunities that have opened up with this pandemic. Urgency tends to cut caution, allowing drugs and devices onto the market without adequate scrutiny, says our editorial this week. ${ }^{8}$ We want to thank all those who have signed the call for more independence from commercial interests in medical research, education, and practice, and we hope that others will add their signatures (bmj.com/commercial-influence). "During this fast moving and lethal pandemic, independent and trustworthy evidence, interventions, and guidance are more important than ever," the editorial concludes.

As the government announced a relaxation of the $2 \mathrm{~m}$ rule on physical distancing, ${ }^{9}{ }^{10}$ now is the time for a rapid, forward looking review of the UK's preparedness for a second wave of covid-19. Healthcare leaders have made this call in an open letter to the UK's political leaders. ${ }^{11}$ We must hope for less target driven chaos and more evidence based strategy in the months to come.

\footnotetext{
Lintern S. Coronavirus: Government must set out better testing strategy to help UK exit lockdown, says laboratories chief. Independent. https://www.independent.co.uk/news/health/coronavirus-testing-target-uk-nhs-lockdown-a9505266.html.

2 Ham C. Chris Ham: A "world beating” test and trace service is far from the current reality. BMJ Opinion. 19Jun 2020. https://blogs.bmj.com/bmi/2020/06/19/chrisham-a-world-beating-test-and-trace-service-is-far-from-the-current-reality.

Mahase E. Covid-19: Local health teams trace eight times more contacts than national service. BM/2020;369:m2486. doi: 10.1136/bmj.m2486 pmid: 32571795

NHS Test and Trace: it didn't have to be this way. BMJ 2020;369:m2471.pmid: 32571787

Baraniuk C. Covid-19 antibody tests: a briefing. BMJ2020;369:m2284.

Andersson M, Low L, French N, etal. Rapid roll out of SARS-CoV-2 antibody testing-a concern. BMJ2020;369:m2420.

Armstrong S. Why covid-19 antibody tests are not the game changer the UK government claims. BMJ2020;369:m2469.

Moynihan R, Macdonald H, Bero L, Godlee F. Commercial influence and covid-19. BM/2020;369:m2456.

Rimmer A. Covid-19: UK prime minister announces relaxation of lockdown and social distancing rules. BMJ2020;369:m2526.

Rimmer A. Sixty seconds on ... the two metre rule. BMJ2020;369:m2507.

1 Adebowale V, Alderson D, Burn W, etal. Covid-19: Call for a rapid forward looking review of the UK's preparedness for a second wave-an open letter to the leaders of all UK political parties. BMJ 2020;369:m2514doi: 10.1136/bmj.m2514.
}

This article is made freely available for use in accordance with BMJ's website terms and conditions for the duration of the covid-19 pandemic or until otherwise determined by BMJ. You may use, download and print the article for any lawful, non-commercial purpose (including text and data mining) provided that all copyright notices and trade marks are retained. 